\title{
Relationship between wood colour of seven tropical hardwood species and formaldehyde emission of plywood
}

\author{
Syafinaz Abd Rashad, Paridah Md Tahir, Rafeadah Rusli, Lee Seng Hua
}

\begin{abstract}
There are many factors that affect the formaldehyde emission from plywood such as wood species and moisture content. As for wood species, colour appearance was found to affect significantly the formaldehyde emission. Therefore, the effects of tropical wood species with different colour on the formaldehyde emission of manufactured plywood were studied and determined by the perforator and desiccator method. Veneer of seven wood species, namely Mempisang, Kedondong, Penarahan, Keledang, Rengas, Melembu and Ludai were chosen as samples. 3-ply plywood were manufactured using urea formaldehyde as binders. The formaldehyde emission of the produced plywood was tested using perforator method (EN 120) and desiccator method (MS 1787: Part 15). Colour of the wood veneers were measured using Brightness \& Colour Meter through CIE $L * a * b *$ system. Relationship between the wood colour and formaldehyde emission were determined. The results revealed that the formaldehyde emission increased as the lightness $\left(L^{*}\right)$ of the wood samples increased. This may be due to higher extractive content in darker coloured wood (low lightness) that acts as formaldehyde scavenger.
\end{abstract}

Index Terms: Tropical hardwood, colour, formaldehyde, relationship, extractives

\section{INTRODUCTION}

In Malaysia, plywood is one of the main wood products and the second largest export item amongst Malaysia's timber and timber products. The Japanese market is a very important for all ASEAN countries and therefore many local wood-based panels manufacturers are geared towards the stringent Japanese formaldehyde requirements in which the productions mainly catered for this purpose. Japan has the most stringent regulation on the maximum allowable formaldehyde emission in the world. In Japan, $\mathrm{F}^{* * *}(\leq 0.5$ $\mathrm{mg} / \mathrm{L})$ and $\mathrm{F}^{* *}(\leq 1.5 \mathrm{mg} / \mathrm{L})$ boards are used restrictedly within a room depending on air exchange and room size while $\mathrm{F}^{* * * *}(\leq 0.3 \mathrm{mg} / \mathrm{L})$ is used unrestrictedly. Since

Revised Manuscript Received on July 05, 2019

Syafinaz Abd Rashad, Institute of Tropical Forestry and Forest Products, Universiti Putra Malaysia, 43400 UPM Serdang, Selangor, Malaysia.

Paridah Md Tahir, Institute of Tropical Forestry and Forest Products, Universiti Putra Malaysia, 43400 UPM Serdang, Selangor, Malaysia. Corresponding author.Email: parida@upm.edu.my

Rafeadah Rusli, Forest Research Institute Malaysia, Jalan Frim, Kepong, 52109 Kuala Lumpur, Selangor, Malaysia

Lee Seng Hua, Institute of Tropical Forestry and Forest Products, Universiti Putra Malaysia, 43400 UPM Serdang, Selangor, Malaysia. Corresponding author. Email:lee seng@upm.edu.my end-products that are exported to Japan, Europe, USA, Australia and other developed countries must meet the maximum allowable level, majority of local manufacturers (furniture or wood-based panel) have experience in working, producing and testing of material with low formaldehyde emission.

According to the personal communication with the local plywood manufacturers during factory visit, application of heterogeneous wood species in plywood manufacturing has been problematic. In the conversation, local manufacturers highlighted out that plywood which contained light coloured wood veneers tend to emit higher level of formaldehyde and resulted in the rejection of the whole batch of production as it exceeded the maximum limit of permissible formaldehyde emission. They claimed that the observation was based on years of experience in working with plywood. Therefore, based on this problem, it is worth to investigate and validate.

Many studies have reported that formaldehyde content is species dependent. For instance, Meyer and Boehme [1] stated that oak wood has the highest formaldehyde emission while beech wood has the lowest. Schafer and Roffael [2] also reported that the formaldehyde emission from softwoods are differed from hardwoods. In a study by Martinez and Belanche [3], the authors suggested that the formaldehyde emission of plywood are affected by the anatomy of the wood species used. The anatomy mentioned here is the porosity of the wood as well as diameter and frequency of the vessels. However, the relationship between the wood colour and formaldehyde emission has yet been reported. The objective of this study is to determine the formaldehyde content in seven tropical wood species with different colour appearances. The formaldehyde emission from the plywood made from these wood species were determined using perforator and desiccator methods.

\section{MATERIALS AND METHODOLOGY}

\section{A. Materials}

Seven tropical wood species, namely Mempisang (Alphonsea spp.), Kedondong (Canarium spp.), Penarahan (Gymnacranthera spp.), Keledang (Artocarpus spp.), Rengas (Gluta spp.), Melembu (Pterocymbium spp.), and Ludai (Sapium spp.) were used in this study. Urea formaldehyde (UF) resin, wheat flour were used as binder. The selection of species was based on the colour, density, and availability as shown in Table 1. 
TABLE 1: SPECIES USED IN THIS STUDY

\begin{tabular}{ccc}
\hline Species & Density $\left(\mathrm{kg} / \mathrm{m}^{3}\right)$ & Colour \\
\hline Kedondong & $495-975$ & Dark-brown \\
Penarahan & $370-770$ & Light red-brown \\
Mempisang & $370-975$ & Light yellow-brown \\
Ludai & $290-465$ & Light yellow-brown \\
Keledang & $500-945$ & Orange-brown \\
Rengas & $640-940$ & Dark red-brown \\
Melembu & $465($ Average $)$ & Pale-brown \\
\hline
\end{tabular}

The veneers used in this study have the following specifications: (i) thickness: $4 \mathrm{~mm}$ (ii) dimension: $400 \mathrm{~mm} \mathrm{x}$ $400 \mathrm{~mm}$, (iii) moisture content: $3-5 \%$ and (iv) type: core veneers. The veneer was cut into the dimension of $400 \mathrm{~mm} x$ $400 \mathrm{~mm} \times 4 \mathrm{~mm}$. The veneer sheets were air-dried and conditioned to $10-12 \%$ moisture content, respectively. The veneers species were delivered to the Laboratory of Biopolymer and Derivatives (BADs), Institute of Tropical Forestry and Forest Product (INTROP) in UPM for the production of experimental plywood.

\section{B. Fabrication of plywood}

Commercial E1-grade Urea Formaldehyde (UF) resin was used to bond the veneers. A total of 28 pieces of 3-ply plywood of $400 \times 400 \times 12 \mathrm{~mm}$ in size were fabricated from seven wood species (4 plywood for each species). The adhesive was applied onto one-side of the veneer surface with adhesive spread rate of $222 \mathrm{~g} / \mathrm{m}^{2}$, single glue line. The veneers were assembled with the grain perpendicular to each other. The consolidated veneers were cold pressed at $0.5 \mathrm{MPa}$ at room temperature followed by hot pressing at $1.0-1.3 \mathrm{MPa}$ and at $120^{\circ} \mathrm{C}$ for 5 minutes. After hot pressing, the panels were conditioned at ambient for 24 hours prior to cutting of test specimens. Three replications were used for each formaldehyde emission test, perforator and desiccator. For desiccator, a total of 9 specimens of dimension $50 \times 150 \mathrm{~mm}$ were cut. In the case of perforator, a sufficient number of specimens $(25 \times 25 \mathrm{~mm})$ was cut to obtain a total weight of $110 \mathrm{~g}$ which depend on the density of the wood.

\section{Determination of formaldehyde and evaluation on wood plywood species}

To determine the formaldehyde for this study, two (2) method were used, i) by Perforator for both wood species and plywood panels and ii) by desiccator only for plywood panels. The perforator method was used to determine the formaldehyde content from wood species and plywood panels as described in EN 120 and for desiccator method as described in MS 1787: Part 15.

\section{Colour measurement}

Colour of wood veneers were measured using Brightness \& Colour Meter (Model No. 68-50-00-0001, Messmer Instruments Ltd) through CIE L*a*b* system. The values were obtained from 3 points of the samples surface. The $\mathrm{L}^{*}$ axis represents Lightness where 0 represents black and 100 represents white. The $a^{*}$ axis is green (represented by $\left.-a\right)$ and red $(+a)$ while the $b^{*}$ axis is blue $(-b)$ and yellow $(+b)$.

\section{RESULTS AND DISCUSSION}

\section{A. Colour of the wood veneer}

Table 2 shows the average colorimeters results for seven species using CIE L*a*b colour systems.

\section{TABLE 2: COLOUR ATTRIBUTES OF SEVEN TROPICAL HARDWOOD SPECIES USING CIE L*A*B* COLOUR SYSTEM}

\begin{tabular}{cccc}
\hline Wood Species & $\mathrm{L}^{*}$ & $\mathrm{a}^{*}$ & $\mathrm{~b}^{*}$ \\
\hline Mempisang & 68.92 & 8.09 & 25.51 \\
Penarahan & 69.23 & 19.87 & 38.85 \\
Kedondong & 72.00 & 17.69 & 21.90 \\
Rengas & 43.05 & 18.92 & 23.58 \\
Ludai & 77.10 & 3.83 & 25.17 \\
Melembu & 75.00 & 7.68 & 31.64 \\
Keledang & 71.57 & 10.39 & 25.60 \\
\hline
\end{tabular}

Based on the results in Table 2, Ludai has the highest lightness $\left(\mathrm{L}^{*}\right)$ of 77.10 , indicating that it is the lightest in colour. On the contrary, Rengas with the darkest colour has the lowest $L^{*}$ value of 43.05 . Reddishness of the wood, representing by the $\mathrm{a}^{*}$ value, revealed that Penarahan (19.87), Rengas (18.92) and Kedondong (17.69) has redder hue compared to the other wood samples. On the other hand, the $b^{*}$ value that describing the yellowness of the samples showed that Penarahan and Melembu are among the wood species that exhibit higher yellowish hue, with respective value of 38.85 and 31.64 .

\section{B. Formaldehyde content and emission of wood veneer and plywood}

The hypothesis of this study is formaldehyde emission from lighter colour wood species are higher compared to the darker colour (lower lightness) wood species. Therefore, the correlation between lightness $\left(\mathrm{L}^{*}\right)$ and formaldehyde content and emission were drawn. Figure 1 illustrated the correlation between lightness of wood and formaldehyde value of veneer and plywood determined by both desiccator and perforator methods. The results revealed the lightness of the wood are directly proportionate to the formaldehyde emission of both wood veneer and plywood. Positive moderate correlations were recorded $\left(\mathrm{R}^{2}=0.30\right.$ to 0.49$)$. It has confirmed the hypothesis of this study where the brighter the wood, the higher the formaldehyde content.

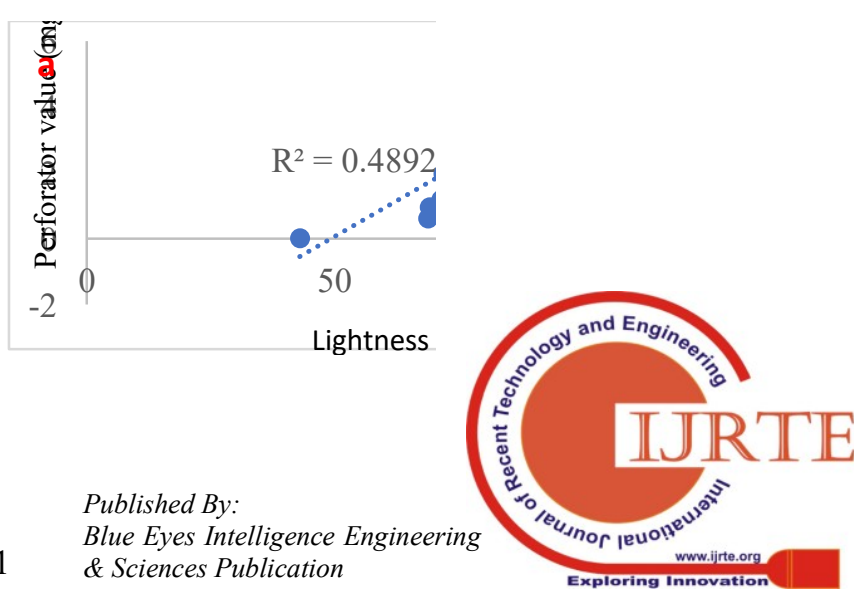



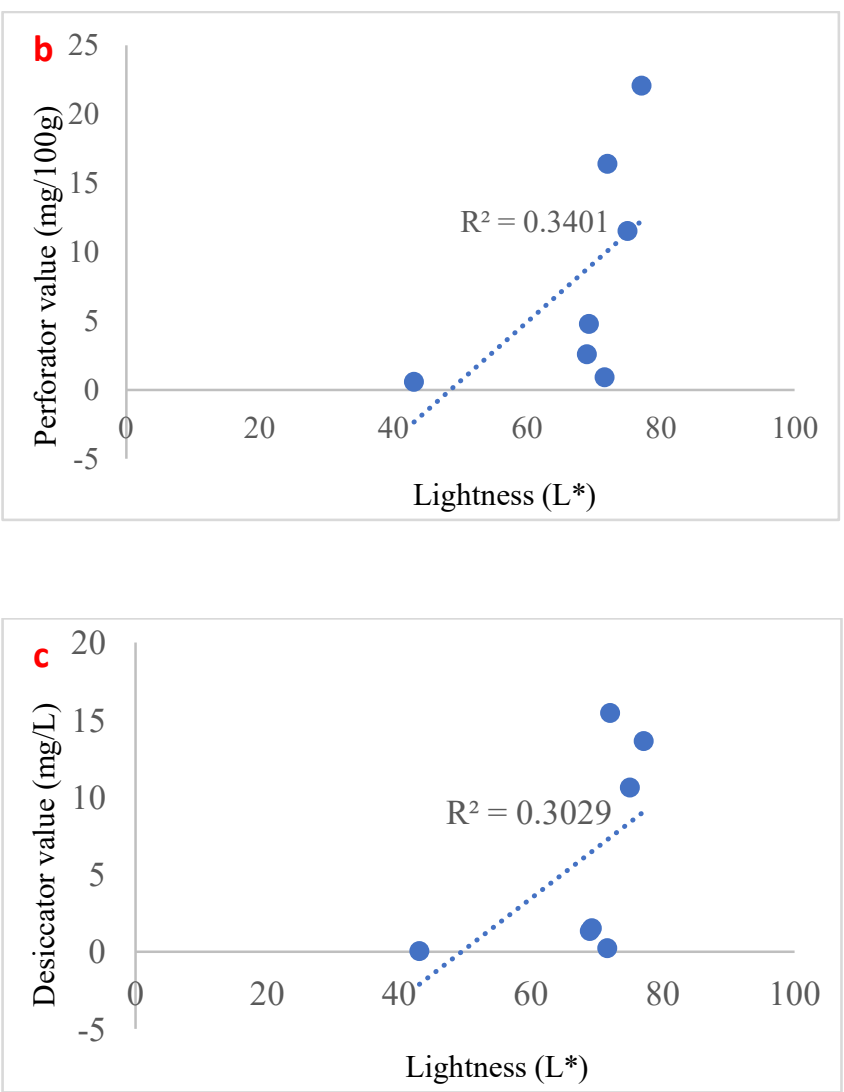

Figure 1: Correlation between wood lightness (L*) and formaldehyde emission of (a) veneer by perforator; (b) plywood by perforator; and (c) plywood by desiccator

\section{Relationship between wood colour and chemical} content

The difference in formaldehyde emission and content from different wood species could be attributed to the difference in extractive content [4-5]. The cell wall chemical content and extractive content of the seven wood species are displayed in Table 4. Mempisang and Rengas are the wood species with the highest extractive content, which is $11.73 \%$ and $9.32 \%$, respectively.

Table 4: Chemical and extractive content of the wood species in this study

\begin{tabular}{lccccc}
\hline \multicolumn{5}{c}{ Composition (\%) } \\
Wood & $\begin{array}{c}\text { Extract } \\
\text { species }\end{array}$ & $\begin{array}{c}\text { Holocell } \\
\text { ulose }\end{array}$ & $\begin{array}{c}\alpha \text {-cellu } \\
\text { lose }\end{array}$ & $\begin{array}{c}\text { Hemicell } \\
\text { ulose }\end{array}$ & $\begin{array}{c}\text { Ligni } \\
\mathrm{n}\end{array}$ \\
\hline $\begin{array}{l}\text { Mempi } \\
\text { sang }\end{array}$ & 11.73 & 58.97 & 48.71 & 10.26 & 19.13 \\
$\begin{array}{l}\text { Penara } \\
\text { han }\end{array}$ & 4.73 & 75.87 & 49.31 & 26.56 & 19.13 \\
$\begin{array}{l}\text { Kedon } \\
\text { dong }\end{array}$ & 4.70 & 75.98 & 46.63 & 29.35 & 18.64 \\
$\begin{array}{l}\text { Rengas } \\
\text { Ludai }\end{array}$ & 9.32 & 77.19 & 42.26 & 30.93 & 24.29 \\
$\begin{array}{l}\text { Melem } \\
\text { bu }\end{array}$ & 3.18 & 86.6 & 46.5 & 40.1 & 20.05 \\
& 2.13 & 98.14 & 69.83 & 28.31 & 20.76
\end{tabular}

Keleda

ng

3.97

85.15

45.72

39.43

19.44

Gierlinger et al. [6] reported in their study that the lightness of the wood decreased as the total amount of extractives increased. The result was in line with the finding in this study as shown in Figure 2. Figure 2 shows the correlation between the lightness of wood and extractive content. The lightness of the wood samples decreased as the extractive content increased. Yazaki et al. [7] suggested that the cell wall chemical components, namely cellulose, hemicellulose and lignin, do not possess any distinctive colour. Therefore, it is the existing of extractive in wood that gives the wood a variety of colours. Gierlinger et al. [6] stated that the lightness $\left(\mathrm{L}^{*}\right)$ and redness $\left(\mathrm{a}^{*}\right)$ of a wood are highly dependent on its extractive content while yellowness $\left(b^{*}\right)$ is depends on the cell wall chemical components.

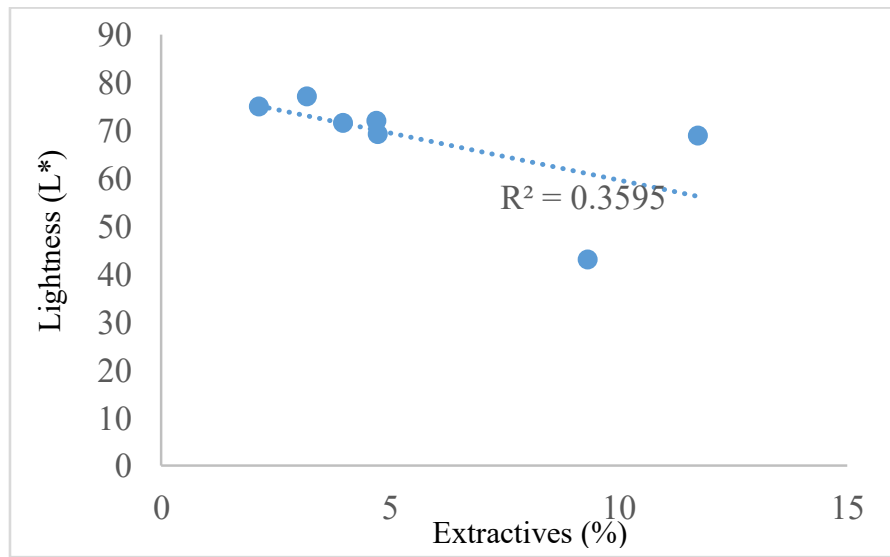

Figure 2: Correlation between lightness (L*) of wood samples and extractive content

Schafer and Roffael [2] reported that certain extractives could act as formaldehyde scavenger by reacting with the formaldehyde and subsequently reduced the emission formaldehyde from certain wood. As the lightness of the wood are inversely proportionate to the extractive content, it could be explained that wood with darker colour possess higher amount of extractives that could scavenge the formaldehyde.

\section{CONCLUSIONS}

The relationship between wood colour and formaldehyde emission of plywood made from different wood species were investigated in this study. From the results, it can be concluded that the wood colour, particularly lightness, has significant effects on the formaldehyde emission. Wood veneer with lighter colour tends to emit higher formaldehyde. Similarly, plywood made from light colour veneer has higher formaldehyde emission. One of the probable reasons is that darker colour wood contains higher amount of extractives that could acts as formaldehyde scavenger. Further investigation is needed to determine other influential factors on the formaldehyde emission such as wood anatomy, density and porosity. 


\section{ACKNOWLEDGMENT}

This project was supported by Higher Institutions' Centre of Excellence (HICoE) and "Determination of formaldehyde emission level and correlation values between perforator, desiccator and small chamber methods to be used by the malaysian plywood industry" funder by Malaysian Timber Industry Board (MTIB).

\section{REFERENCES}

1. B. Meyer, and C. Boehme, "Formaldehye emission from solid wood," Forest Products Journal, vol.5, 1997, pp. 45-48.

2. M. Schafer, and E. Roffael, "On the formaldehyde release of wood,", Holz als Roh- und Werkstoff, vol.58, 2000, pp. 259-264.

3. E. Martinez, and M.I. Belanche, "Influence of veneer wood species on plywood formaldehyde emission and content," Holz als Roh- und Werkstoff, vol.58, 2000, pp. 31-34.

4. R. Moya, R.S. Fallas, P.J. Bonilla, and C. Tenorio, "Relationship between wood color parameters measured by the CIELab system and extractive and phenol content in Acacia mangium and Vochysia guatemalensis from fast-growth plantations," Molecules, vol.17, 2012, pp. 3639-3652.

5. W. Ding, W. Li, Q, Gao, C. Han, S, Zhang, and J. Li, "The effects and sealing treatment and wood species on formaldehyde emission of plywood," BioResources, vol.8, 2013, pp. 2568-2582.

6. N. Gierlinger, D. Jacques, M. Grabner, R. Wimmer, M. Schwanninger, P. Rozenberg, and L.E. Paques, "Colour of larch heartwood and relationships to extractives and brown-rot decay resistance," Trees, vol.18, 2004, pp. 102-108.

7. Y. Yazaki, "Wood colors and their coloring matters: a review," Natural Product Communications, vol.10, 2015, pp. 505-512.

\section{AUTHORS PROFILE}

Syafinaz Abd Rashad is a Master student from Institute of Tropical Forestry and Forest Products, Universiti Putra Malaysia. She is currently in her fifth semester.

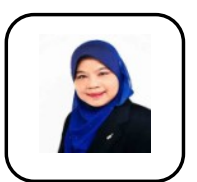

Paridah Md Tahir is a research associate from Institute of Tropical Forestry and Forest Products, Universiti Putra Malaysia, majoring in wood adhesive.

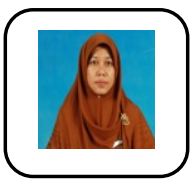

Rafeadah Rusli is a research officer from Forest Research Institute Malaysia, majoring in wood chemistry.

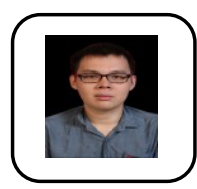

Lee Seng Hua is a research fellow from Institute of Tropical Forestry and Forest Products, Universiti Putra Malaysia, majoring in wood science and technology. 